$=14)$

connonwealtn of :assachusetts

jepertinent of Public „orks

,.. $\therefore$ Calla!ran, Contissioner i. S. jepartinent of the Interior veological Survej

i.. E. .retior, Director

$=2,116]$

\author{
Cooperativg Geolojic Project \\ Geologic Interpretation of jeismic jata \\ Rolocation Route 2 \\ Littleton Road Grade Separation \\ Stations 243-252 \\ in Harvard, Less.
}

by

James E. :aynard, jeolozist, J. S. Geolozical Surve:

and

Rev. Janiel Lineisn, S. J., Seismolozist, ..uston College

4 pages of text

2 plates $\checkmark$

- geological. surver

MASS. DEPT. OF PUBLIC WORKS Cooperative Geologic paoject

OPEN FILE REPORT

$\therefore$ this report have been placed in open files for public inspection at i.')LOGICAL SURVEY, ENGINEERING GEOLOGY BRANCH, I.IBRARY, FEDERAL WOKKS B'LD'G, WASHINGTON, D. C. 'I, (GICAL SURVEY, 100 NASHUA ST., ROOM 802, BOSTON - II HUSETTS.

"HINETTS DEPT. of PUBLIC WORKS, PROJECT ENGINEER

$\because$ ISHUA ST, BOSTON, MASSACHUSETTS 
Ge0lozic Interpretation of Seismic Lata

Relocation Route a

Littleton Road Grade Separation

Stations 243-252

in Harvard, liass.

by

James E. Laynarc, Geolozist, U. S. Geological Survey

and

Kev. Laniel Linehan, s. J., jeismclöist, .eston College

\section{Genersi statement}

Durinę parts of June and July luto nine seismic traverses were made at tiais site. Jpon preliminary office develcpment, the velocity date for some of tnese traverses were thoucht to be inadocuate and it vas recomended that these linos be re-surveyed. Later surveys ( $\because$ arch 1550), hovever, of neary sites indicated tiat tive orioginal date were reliable and tiat \& re-curvey was unnecessary

The work was lone is pert of a cooperative prourar. of the iassachusetts Lepartment of rublic .orks and the United State Geolorical Surveje

\section{Surfece Geolog}

At this location the proposed radsite treverses a nearly horizontal, bench-like area on the nortiern slope of a till nill. inere sampled the till is mojerately loose, scientat ssnay, ard is overlain 
by a thin luyer, a few inches to a fow feet thick, of fine silt anc sand. At the overpass site numerous boulcers of contorted mica schist are scattered over the surface. iany large angular blocks of granite and related rock, however, occur just to the west of the overpass site botwecn stations $240+50$ anc 243 .

The bedrock underlying most of the site is probably mica schist, for this type of rock, with a trend that iould project to the site, is grposed alcn Littleton noad sever:l rundred feet to the east of the overpass site. In sdiiticn, a small mass of mica schist, that

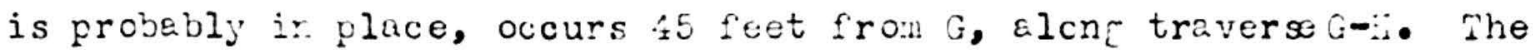
Eeolocy of the site and of the surroundire refion stroncly suchest that bedrock is close to the surface at this location.

\section{Seismic Ireverses}

The layout of the seismic traverses is shom on shoot 1 . The traverses anc their lencths are:

\begin{tabular}{|c|c|c|c|}
\hline$A-3$, & $330 r \in e t$ & I-i, & 105 \\
\hline$i-i$, & $330 "$ & $x-i$, & 105 \\
\hline و & 220 & $\therefore-i n$ & 165 \\
\hline & $\begin{array}{l}220 \\
165\end{array}$ & $\mathrm{P}-4$ & 160 \\
\hline
\end{tabular}

The shot points for the traverses were lockted as follows:

\begin{tabular}{|c|c|c|c|c|c|c|c|}
\hline $\begin{array}{l}\text { SO, } \\
\text { E, }\end{array}$ & statiun & $\begin{array}{l}251+30 \\
245+C 0\end{array}$ & & & & & \\
\hline C, & 124 feet & to $\operatorname{trn} \theta$ & riont & (south) & of & station & $2 \div 4+95$ \\
\hline D, & so " & " $"$ & $l \in f t$ & (rooth) & " & " & $243+0.5$ \\
\hline E, & 511 & " " & $"$ & $"$ & $"$ & $"$ & 246 \\
\hline E, & $\begin{array}{l}\text { stiticn } \\
50 \text { feat }\end{array}$ & $\begin{array}{l}243+\varepsilon 0 \\
\text { to the }\end{array}$ & $"$ & $"$ & $"$ & " & $243+57$ \\
\hline
\end{tabular}




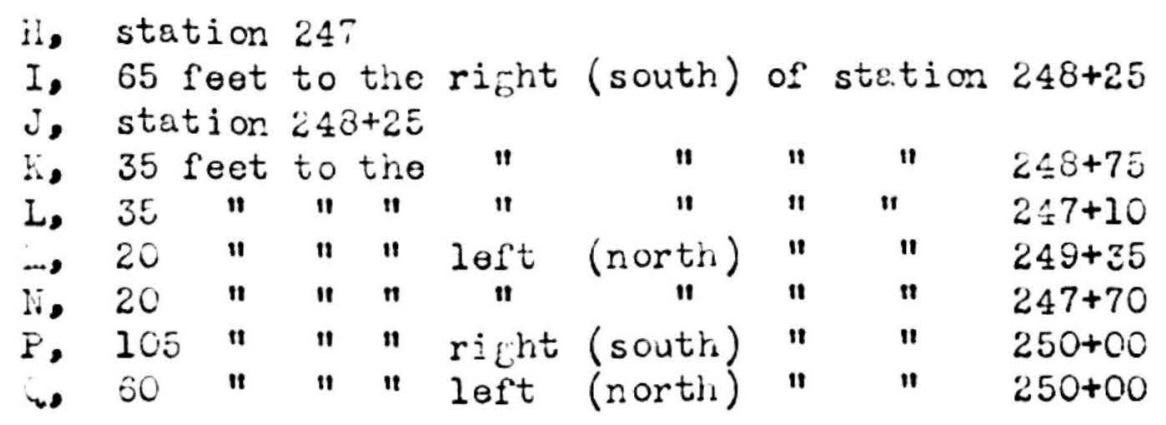

\section{Lepths to jeirock}

The depths to bedrock at the shot points as celculated from the seismic data are as follows:

\begin{tabular}{|c|c|c|c|c|c|}
\hline$\dot{s}=-$ & $\therefore$ feet & $I-$ & 11 & $f \in \theta t$ & \\
\hline- & $7 \quad 11$ & j - & 9 & 11 & \\
\hline $\mathrm{C}-$ & 5 & $z-$ & 7 & $"$ & $(\epsilon \operatorname{simate})$ \\
\hline I- & 5 & L - & 10 & $"$ & \\
\hline$E-$ & 10 & $3-$ & 8 & $"$ & \\
\hline$F-$ & 8 & $N-$ & 9 & $"$ & \\
\hline$G-$ & 5 & $P-$ & 7 & $"$ & \\
\hline E. - & 8 & $5-$ & 13 & " & \\
\hline
\end{tabular}

\section{Geolofic Interpretation of Seismic Late}

The interpreted positions of the bedrock surfaces along the seismic traverses between the shot points art si:own on the feolofic sections, sheet 2. These surfyces are shown on th? sections by snooth curves, but they nust be considered only as Eeneralized approximations, for mary smell ridges, knobs, and depressions may occur at altitudes that are above and below these clurves.

The depth values for most of the shot points were calculated from an estimated average till velocity of 2500 feet per second. irom experience elsewhere, ho.ever, this estinated velccity is believed to be 
very close to tino actual velocity of the material, so that the depth values and general altitudes of the bedrock profiles can be considered reasonably reliable.

Lost of the velocity date for truverse L-Y were confused and inedecuate. The position of the bedrock surface for most of this section is dotied, with the depth valus e.t $\mathrm{K}$ beir. only a rough estinate. The deptr value at $L$ may be considered cood, but, in Eenoral, the information Eiven by this section must be considered only as a very roüh approximation. 


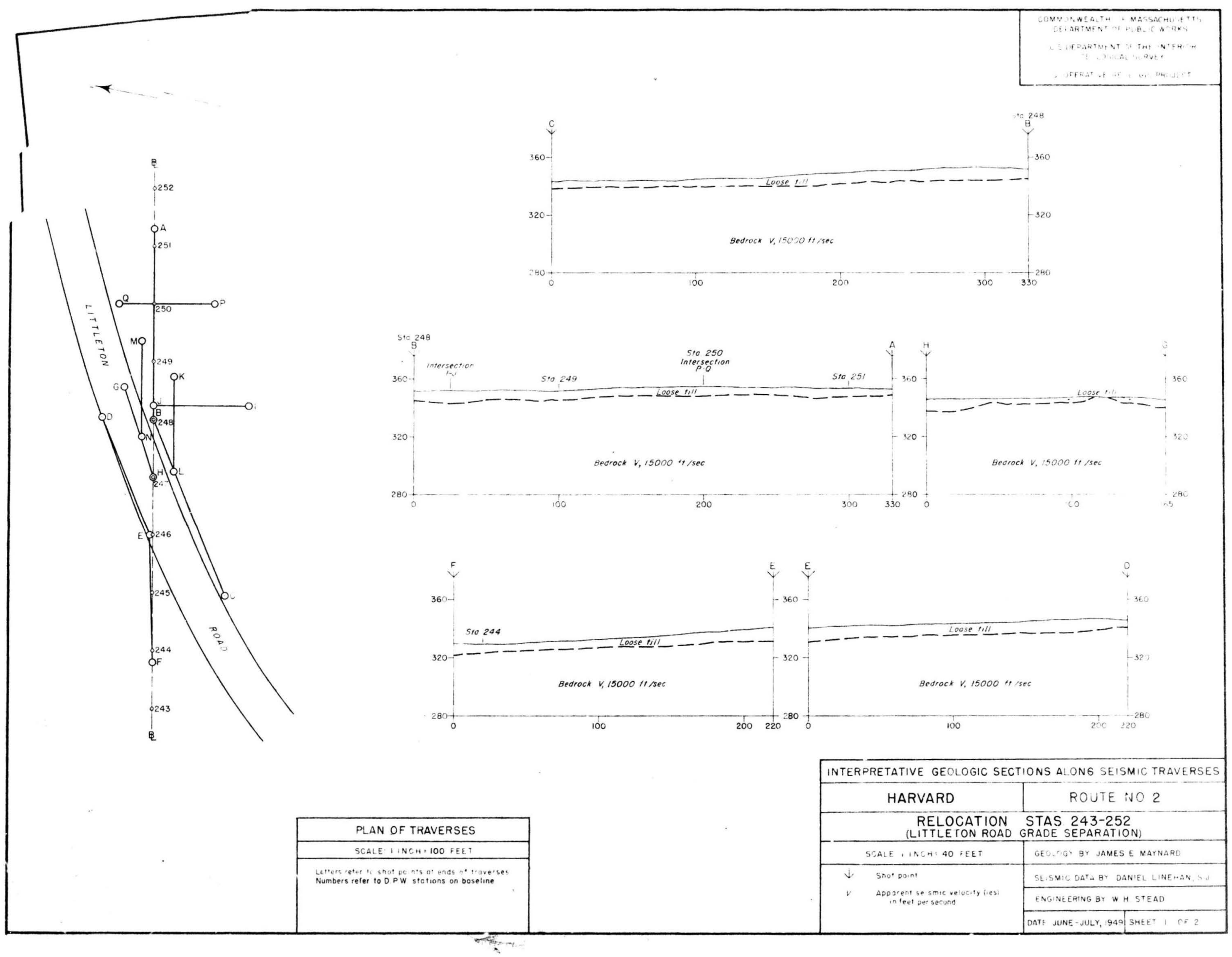



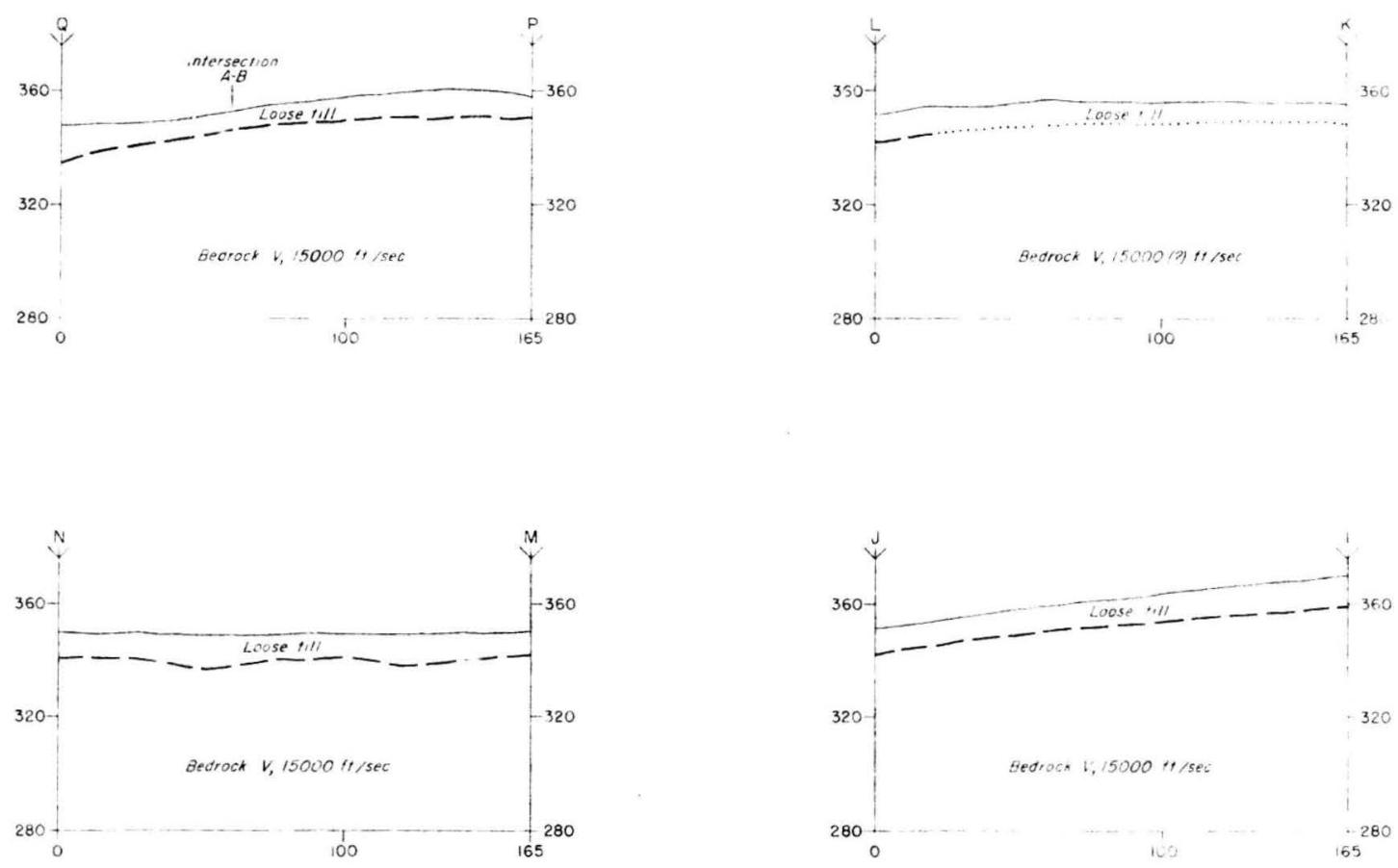

PLAN OF TRAVERSES

NOTE:

Dottec portions of sections indicate

INTERPRETATIVE GEOLOGIC SECTIONS ALONG SEISMIC TRAVERSES HARVARD ROUTE NO 2

\begin{tabular}{|c|}
\hline PLAN OF TRAVERSES \\
\hline SCALE; I INCH: FEE' \\
\hline \\
\hline
\end{tabular}

RELOCATION STAS 243-252

(LITTLETON ROAD GRADE SEPARATION

inconclissue sersmic dora

\begin{tabular}{|c|c|c|}
\hline \multicolumn{3}{|c|}{$\begin{array}{l}\text { RELOCATION STAS } 243-252 \\
\text { (LITTLETON ROAD GRADE SEPARATION) }\end{array}$} \\
\hline & 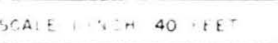 & GE \\
\hline & \multirow{3}{*}{ 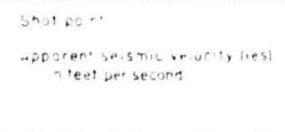 } & 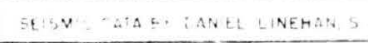 \\
\hline & & ENG NEETING $\&$ W T STEAD \\
\hline & & DAT: JURE JULY, 1949 SHEF' \\
\hline
\end{tabular}

